\title{
THE ANALYSIS OF ATTITUDES OF TAX AMNESTY NON- BENEFICIARIES AND TAX AMNESTY BENEFICIARIES: EVIDENCE FROM TURKEY
}

\author{
Ufuk GERGERLİOĞLU
}

Assist. Prof. Dr., Hitit University, TURKEY, E-mail: ufukyunus@gmail.com

\section{ABSTRACT}

Tax amnesties are applied by many countries on different grounds throughout the world. Governments want to realize social, political, economic, etc. purposes through tax amnesties. It is important that some matters should be clarified within the scope of being realized of these purposes. One of these matters is related to attitudes of tax amnesty non-beneficiaries and tax amnesty beneficiaries. Within this framework, this research aims to reveal attitudinal tendencies of tax amnesty non-beneficiaries and tax amnesty beneficiaries. In this context, this study was conducted for 609 businesses located in Istanbul by using a face-to-face survey method. The data obtained for this study were analyzed with the help of frequency and factor analysis. The result of research indicates that both tax amnesty non-beneficiaries and tax amnesty beneficiaries give similar reactions regarding attitude statements about tax amnesties. But, tax amnesty non-beneficiaries support attitude statements about tax amnesties more than tax amnesty beneficiaries.

Key Words: Attitude, Tax Amnesty, Factor Analysis, Turkey

JEL Codes: H32, H29 


\section{INTRODUCTION}

Tax amnesty is applied to collect previously uncollected taxes and to register unregistered taxpayers (Karg1, 2011: 112). There are many reasons for the implementation of tax amnesties. These can be ranked in the form of political, economic, financial, social, administrative, technical and psychological reasons (Tekin et al., 2013: 7). In addition to these reasons, tax amnesties may also be applied for the purpose of increasing tax revenues in the short term (Alm, 1998). At the same time, tax amnesties can be implemented with the aim of registering previously unreported offshore accounts and thereby increasing investment and growth (Baer and Borgne, 2008: 66).

Tax amnesty has many positive effects including the expansion of the tax base, the reduction the collection costs, the increase in tax compliance, etc. (Karg1, 2011: 112). Further, a tax amnesty can also be considered as a part of policies regarding tax compliance (Andreoni, 1991: 158) The success of a tax amnesty can vary depending on its effects on tax compliance in the short and long term (Torgler, 2007: 268). Further, when it is considered that the main provider of tax compliance is tax justice (Benk et al., 2012: 117), the success of the tax affair can be related to the provision of tax justice. On the other hand, if tax amnesties become permanent, the tax payment consciousness may cease to exist, the deterrence of the penalties may disappear and the tax morals may deteriorate (Edizdoğan and Gümüş, 2013: 115-116). In addition to these, it is alleged that trust on the government may be reduced due to frequent repetition of tax amnesty (Demir et al., 2016: 284).

If tax amnesties are repeated frequently in a country, the taxpayers may not want to carry out their tax responsibilities (Saraçoğlu et al., 2011: 103). In addition to all of these, it is necessary to improve the deficiencies of the tax system before talking about or implementing tax amnesties (Savaşan, 2006: 61). At the same time, giving up on punishment and interest through tax amnesty can also mean loss of tax revenue (Uchitelle, 1989: 53). Applying the tax amnesty alone may not be enough. Furthermore, it is necessary to educate taxpayers about their responsibilities, to take measures in order to improve the tax system and to implement severe penalties for tax evasion (Tuay and Güvenç, 2007: 140). On the other hand, it should not be forgotten that a number of government benefits are undermining justified reasons for tax evasion (McGee et al., 2016: 5).

Tax amnesty can be applied in both developed and developing countries (Karg1, 2011: 112). Tax amnesties have been enforced in countries all over the world such as Argentina, Colombia, India, Malaysia, Pakistan, France, Belgium, Italy, Switzerland, Ireland, Australia, New Zealand, Mexico, Chile (Alm, 1998). Tax amnesties have also been implemented in Turkey in recent years. Tax amnesties continue to remain on the agenda in Turkey even today.

\section{EXPLANATION OF PREVIOUS STUDIES CONDUCTED REGARDING TAX AMNESTY}

Alm and Beck (1993) studies the long run impact of the tax amnesties in the United States. The results of this study show that tax amnesties will not have a significant impact in terms of new revenue generation capacity. The result of a study conducted by Christian et al. (2002) regarding income tax amnesty shows consistency with the conclusion of research conducted by Alm and Beck (1993). On the other hand, the result of a research conducted in Spain by Laborda and Rodrigo (2003) with the aim of revealing the relationship between tax amnesty and tax compliance shows that tax amnesties do not have an effect on tax collection. Torgler et al. (2003) have done an empirical study on how tax amnesties would have an impact on Costa Rica and Switzerland, which have different cultures. According to the result 


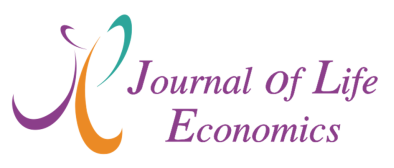

of this empirical research, if people were given the opportunity to vote for tax amnesty, this would contribute to the tax compliance process.

According to a survey conducted by Tuay and Güvenç (2007) on Turkey, 73.8\% of the respondents think that tax amnesties are beneficial to tax evaders. Same research results show that $68.5 \%$ of the participants think that if a taxpayer learns that tax amnesty will have effect in the near future, he or she may be able to avoid some tax liability. Additionally, these research results reveal that $73.7 \%$ of the participants stated that taxpayers who pay taxes regularly may face injustice when tax amnesty is applied, except for crisis periods. Çelikkaya and Gürbüz (2008) conducted a survey regarding effects of taxation on the attitudes of taxpayers in Turkey. The results of this research show that supportive attitudes towards tax amnesty may increase as the level of education increases. According to the same research results, those who participated in the survey think that continuous amnesties can have a negative impact on income distribution. İpek and Kaynar (2012) conducted a study in Turkey on how tax amnesties affect the psychology of the taxpayers. The result of this research show that tax amnesties can lead to repetition of tax offences. Furthermore, the results of this research show that tax amnesties can lead to tax evasion negatively, affect tax justice and punish honest taxpayers. Demir et al. (2016) conducted a survey on how tax authorities assess tax amnesties in Turkey. The results of this research reveal that the economic and social objectives that are thought to be reached by tax amnesty cannot be fully attained.

\section{GENERAL ASPECTS OF THE RESEARCH METHOD}

Under this heading, firstly, general information is given about the methodology of the research. Afterwards, the data regarding the findings of the research is revealed. All information and data for research are based on either statistics or official sources.

\subsection{The Aim of the Research}

This research aims to analyze the attitudes regarding tax amnesties of business owners and business shareholders who have businesses in Istanbul. The results of this research were assessed by benefitting from frequency and factor analyzes. Factor analysis was preferred because it was used in a small number of field studies in Turkey. Therefore, instead of nonparametric tests, factor analysis was used. Non-parametric tests constitute the subject of another study.

\subsection{Research Methodology}

This study was conducted in the first quarter of 2017 in both large and small businesses in Istanbul, Turkey. The reason for not differentiating between big and small businesses is that there is no official data about size categories of businesses located in Istanbul. This arises from the inability to go to all the provinces due to insufficient resources. The face-to-face survey method was adopted when this research was conducted. In this context, the statistical population of this field survey is 279.662 businesses (total of 12 districts). Istanbul Chamber of Commerce data, dated January 18, 2017, was taken as the basis when this figure was determined. 609 samples were randomly selected from this statistical population. Male and female business owners or partners were interviewed in this study. The data obtained during this study by means of the survey was analyzed by the Package for Social Science (SPSS), version 19.0 for Windows. 28 attitude statements, 7 demographic questions and 4 other questions were directed to business owners or partners participating in this research. The confidence interval for this study was defined as $95 \%$ (0.95). The sampling error margin related to the survey was determined as $4 \%$. 


\subsection{Research Findings}

First of all, information regarding sample quota is given here. Subsequently, demographic and other data obtained in the study are published. Finally, result of reliability test for the obtained data is mentioned.

\subsubsection{Determining of Sample Quota regarding Stratified Random Sampling Type}

Stratified random sampling is a sample identification method which is used for the purpose of reducing errors in sampling. In this method, units in relation to statistical population are divided into strata, and thereafter the sample is determined according to these strata (Black, 2010: 221). The aim of this method is to increase the representation power of sampling. Stratification is usually used for demographic characteristics such as age, income level, and gender (Polit and Back, 2004: 297). The stratification for this study was done on the basis of sex and district. Data for men and women at the business owner or partner level for year 2015 are provided on the official website of the Republic of Turkey Social Security Institution. According to the official figures in 2015, the number of women business owner or partner working in Istanbul is 127.197. According to the same resource, the number of men business owner or partner working in Istanbul is 377.180. In the context of this data, stratified random sampling-based sex quota was defined as 150 males and 450 females. These figures for men and women were made by taking into account the sex ratio within the total statistical population. In addition, the quota was determined by taking into account the proportion of the districts in the total statistical population, at the time when the data related to the 12 districts was compiled (Table 1).

Table 1. Sample Quota regarding Stratified Random Sampling Type

\begin{tabular}{|c|c|c|c|c|c|c|}
\hline District Name & $\begin{array}{c}\text { Number } \\
\text { of } \\
\text { Businesses }\end{array}$ & $\begin{array}{c}\text { Number of Businesses in } \\
\text { the District / Total } \\
\text { Number of Businesses in } \\
12 \text { Districts }\end{array}$ & $\begin{array}{c}\text { Quota Determined } \\
\text { according to Sampling } \\
\text { Error Margin }\end{array}$ & $\begin{array}{c}\text { Male } \\
\text { (Business } \\
\text { Owner or } \\
\text { Partner) }\end{array}$ & $\begin{array}{l}\text { Female } \\
\text { (Business } \\
\text { Owner or } \\
\text { Partner) }\end{array}$ & TOTAL \\
\hline Ataşehir & 21.701 & $7,8 \%$ & 47 & 35 & 12 & 47 \\
\hline Bağcılar & 19.929 & $7,1 \%$ & 43 & 32 & 11 & 43 \\
\hline Bahçelievler & 18.282 & $6,5 \%$ & 39 & 29 & 10 & 39 \\
\hline Beşiktaş & 17.838 & $6,4 \%$ & 38 & 29 & 10 & 38 \\
\hline Beyoğlu & 19.988 & $7,1 \%$ & 43 & 32 & 11 & 43 \\
\hline Esenyurt & 19.565 & $7,0 \%$ & 42 & 31 & 10 & 42 \\
\hline Fatih & 36.791 & $13,2 \%$ & 79 & 59 & 20 & 79 \\
\hline Kadıköy & 33.192 & $11,9 \%$ & 71 & 53 & 18 & 71 \\
\hline Küçükçekmece & 16.119 & $5,8 \%$ & 35 & 26 & 9 & 35 \\
\hline Şiş̧li & 34.747 & $12,4 \%$ & 75 & 56 & 19 & 75 \\
\hline Ümraniye & 25.338 & $9,1 \%$ & 54 & 41 & 14 & 54 \\
\hline Üsküdar & 16.172 & $5,8 \%$ & 35 & 26 & 9 & 35 \\
\hline TOTAL & 279.662 & $100,0 \%$ & 600 & 450 & 150 & 600 \\
\hline
\end{tabular}

\subsubsection{General Evaluation of Information on Demographic Data}

449 men and 160 women were interviewed for this study. This data demonstrates compatibility with the gender quota determined for the study. 462 of the interviewed individuals are married and 147 are single. 138 individuals who participated in the survey are university graduates. The income level of the participants in the survey is mostly between 1000TL-5000TL (Turkish Lira). While 253 individuals participating in the survey benefited from tax amnesty, 356 did not benefit from it. Within the scope of this research, with 48 people in Ataşehir, with 43 people in Bağcılar, with 39 people in Bahçelievler, with 39 people 


\section{$\int\left(\begin{array}{c}\text { Journal of Life } \\ \text { Economics }\end{array}\right.$}

in Beşiktaş, with 43 people in Beyoğlu, with 42 people in Esenyurt, with 81 people in Fatih, with 71 people in Kadıköy, with 35 people in Küçükçekmece, with 76 people in Şişli, with 55 people in Ümraniye and with 37 people in Üsküdar were interviewed. The number of people interviewed for each district is in accordance with the previously determined district quotas.

\subsubsection{Result of the Reliability Analysis Regarding the Research}

Many statistical methods are used to test whether the scale is reliable. One of the most common methods is the Cronbach Alpha Coefficient method. This method provides information about the internal consistency of the scale (İslamoğlu and Alnıaçık, 2014: 283). The Cronbach's Alpha Coefficient that is smaller than 0,5 is unacceptable; between 0.5 (equal to 5) and 0,6 is bad; between 0,6 (equal to 6) and 0,7 is suspicious; between 0.7 (equal to 7) and 0.8 is acceptable; between 0,8 (equal to 8) and 0,9 is good (Westland, 2015: 92). The Cronbach's Alpha Coefficient for this study is 0,808 (Table 2). It is possible to say that this result is good within the scope of the statistical literature.

Table 2. Cronbach's Alpha Value regarding the Researh

\begin{tabular}{|c|c|c|}
\hline Cronbach's Alpha & Cronbach's Alpha Based on Standardized Items & N of Items \\
\hline, 808 &, 824 & 28 \\
\hline
\end{tabular}

\section{ANALYSIS OF DATA REGARDING THE RESEARCH}

Firstly, the results of frequency analysis are discussed under this heading. Afterwards, the results of the factor analysis are mentioned. The results of these analyses are explained through the tables.

\subsection{Evaluation of the Results of Frequency Analysis related to this Research}

First of all, the opinions on attitude statements of the tax amnesty beneficiaries are evaluated here. After that, the views regarding the attitude statements of the tax amnesty nonbeneficiaries are discussed. Finally, the results of the frequency analysis regarding attitude statements between the participants who have and have not benefited from tax amnesty before are compared under this heading. When these evaluations were made, the percentage of 'I agree' regarding the attitude statements of the taxpayers participating in the survey were taken into account.

\subsubsection{Interpretation of Opinions on Attitude Statements Tax Amnesty Beneficiaries}

Table 3 shows the analysis of the frequency regarding attitude statements of the tax amnesty beneficiaries. This table reveals that the number 1 attitude statement $(79.4 \%)$ was the most favored by those who participated in the survey. This result regarding the attitude statement no. 1 exhibits that the tax amnesty beneficiaries take more account of the macroeconomic frame of the country in assessing the tax amnesty. Additionally, Table 3 indicates most of participants $(76.7 \%)$ who have benefited from the tax amnesty before support tax amnesties for small (micro) businesses. When the attitude statements 3 and 4 are looked at, most of the participants $(75.5 \%)$ who have benefited from the tax amnesty before think that tax amnesties will be beneficial to improve the economic situation in their country. Other salient results related to this table can be listed as follows; 


\section{$\int\left(\begin{array}{c}\text { Journal of Life } \\ \text { Economics }\end{array}\right.$}

-Most of the participants in this research think premium amnesties have a higher priority than tax amnesties. This result is seen in the frequency rates of attitude statements 10 $(70 \%)$ and $11(69.6 \%)$ in Table 3.

-Only $32.8 \%$ of respondents support the application of tax amnesties only once. At the same time, $24.1 \%$ of the respondents support the increase of tax penalties after the application of tax amnesty.

When supportive views of these two attitudes are evaluated together it can be seen that the taxpayers are under the influence of tax amnesties.

-The rate of respondents who see tax amnesties as a fair practice is $55.7 \%$

$-38.7 \%$ of the respondents think that tax amnesties will lead to an unfair competition.

When these results are viewed together, the tax amnesty beneficiaries generally support tax amnesties. These results show that the tax amnesty beneficiaries will evaluate tax amnesties optimistically even if the majority of the participants do not consider the tax amnesty fair.

Table 3. Analysis of Attitude Statement Frequency of Tax Amnesty Beneficiaries

\begin{tabular}{|c|c|c|}
\hline NO & ATTITUDE STATEMENTS & I AGREE \\
\hline 1 & When it comes to a serious economic downturn, I may support the tax amnesty & 79,4 \\
\hline 2 & $\begin{array}{l}\text { A tax amnesty that will come into effect for small businesses (micro business) in the future will make } \\
\text { me happy }\end{array}$ & 76,7 \\
\hline 3 & I care about reviving in the economy because of the tax amnesty & 75,5 \\
\hline 4 & I believe that tax amnesties must come into force for sectors that are struggling & 75,5 \\
\hline 5 & $\begin{array}{l}\text { Tax amnesties can make the business life of taxpayers who get down due to not fulfilling their } \\
\text { tax obligations more efficient }\end{array}$ & 73,1 \\
\hline 6 & $\begin{array}{l}\text { The fact that tax amnesties come into effect at regular intervals can affect my economic decisions } \\
\text { positively }\end{array}$ & 72,7 \\
\hline 7 & I think that the revenues from tax amnesties will provide an important contribution to the state treasury & 72,3 \\
\hline 8 & I think that tax amnesties are an important way to concord with the state & 71,5 \\
\hline 9 & I think that tax amnesties will boom the economy & 71,5 \\
\hline 10 & I think that tax amnesties are important agreements to make peace with the state. & 70,0 \\
\hline 11 & I care more about the enactment of premium amnesties than the enactment of tax amnesties & 69,6 \\
\hline 12 & Tax amnesties can facilitate the transition of taxpayers from informal to formal economy & 68,4 \\
\hline 13 & The fact that tax amnesties come into effect at certain periods can affect my mood positively & 67,6 \\
\hline 14 & The fact that tax amnesties could come into force at any time gives me confidence & 66,4 \\
\hline 15 & I believe that tax amnesties should come into effect at regular intervals & 66,4 \\
\hline 16 & I think that if taxpayers benefit from tax amnesty, that they should be audited more strictly & 63,2 \\
\hline 17 & I believe that instead of tax amnesties, tax audits should be done more frequently & 59,7 \\
\hline 18 & Tax amnesty can strengthen the cooperation between the taxpayer and the tax administration & 59,7 \\
\hline 19 & I believe tax amnesty is a fair practice & 55,7 \\
\hline 20 & I think that if taxpayers benefit from tax amnesty, they will be more conscious of tax responsibilities & 55,3 \\
\hline 21 & I believe that if taxpayers benefit from tax amnesty, they may pay the taxes more diligently in the future & 54,9 \\
\hline 22 & Tax amnesties implemented at certain times can lead to pay less tax & 44,7 \\
\hline 23 & I think that tax amnesties appear like rewards given to dishonest taxpayers & 39,9 \\
\hline 24 & Tax amnesties can encourage taxpayers to pay more taxes & 39,5 \\
\hline 25 & I believe that tax amnesties will lead to an unfair competition in the economy & 38,7 \\
\hline 26 & I think that tax amnesties weaken the authority of tax auditing & 34,0 \\
\hline 27 & I believe that taxpayers should benefit from tax amnesties only once & 32,8 \\
\hline 28 & I believe that tax penalties should be aggravated immediately after the tax amnesty has come into effect & 24,1 \\
\hline
\end{tabular}




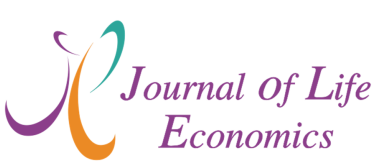

\subsubsection{Interpretation of the Views regarding Attitude Statements of the Tax Amnesty Non-Beneficiaries}

Table 4 reveals that analysis of the frequency in relation to attitude statements of the respondents who have not benefited from the tax amnesty before. This table shows that the number 1 attitude statement $(84.3 \%)$ was most approved by those who participated in this research. This conclusion of attitude statement number 1 demonstrates that the respondents who have not benefited from the tax amnesty before take more into consideration the general economic conditions of the country when they assess tax amnesties. On the other part, Table 4 shows that most of respondents $(77.8 \%)$ who have benefited from the tax amnesty before advocate tax amnesties towards small (micro) businesses. The attitude statements 2 and 4 indicate that many of the respondents $(82.9 \%, 77.8 \%)$ who have not benefited from the tax amnesty before believe that tax amnesties will become helpful in terms of economic development in their country. Other outstanding conclusions in relation to this table may be ranked as follows;

-Many of the respondents who have not benefited from the tax amnesty before expect that premium amnesties will give better results in comparison to tax amnesties. This conclusion is understood from the frequency rates of attitude statements 8 (74.4\%) and 14 $(70.2 \%)$ in table 4 .

$-31.2 \%$ of respondents who have not benefited from the tax amnesty before express that if tax amnesty is implemented only once, they will support it.

$-18.3 \%$ of them state that if tax penalties increase after the application of tax amnesty they will advocate it as well. Supportive opinion on these two attitude statements show that the taxpayers will be impressed by implementation regarding tax amnesties.

$-60.4 \%$ of respondents who have not benefited from the tax amnesty before express that tax amnesties are a fair practice. Opinion towards "tax amnesties will lead to an unfair competition" attitude statement is supported by $34.3 \%$ of respondents who have not benefited from the tax amnesty before.

-All these results indicate that the respondents who have not benefited from the tax amnesty before advocate tax amnesties typically. At the same time, these results show that the tax amnesty non-beneficiaries will assess tax amnesty affirmatively even though the majority of the respondents have not benefited from the tax amnesty before did not see practice it as fair. 


\section{$\int\left(\begin{array}{c}\text { Journal of Life } \\ \text { Economics }\end{array}\right.$}

Table 4. Analysis of the Frequency in relation to Attitude Statements of the Tax Amnesty Non-Beneficiaries

\begin{tabular}{|c|c|c|}
\hline NO & ATTITUDE STATEMENTS & $\begin{array}{c}\text { I } \\
\text { AGREE }\end{array}$ \\
\hline 1 & When it comes to a serious economic downturn, I may support the tax amnesty & 84,3 \\
\hline 2 & I believe that the tax amnesties must come into force for sectors that are struggling & 82,9 \\
\hline 3 & I care about reviving in the economy because of the tax amnesty & 77,8 \\
\hline 4 & $\begin{array}{l}\text { A tax amnesty that will come into effect for small businesses (micro business) in the future will make me } \\
\text { happy }\end{array}$ & 77,8 \\
\hline 5 & $\begin{array}{l}\text { Tax amnesties can make the business life of taxpayers who get down due to not fulfilling their } \\
\text { tax obligations more efficient }\end{array}$ & 76,7 \\
\hline 6 & I think that the revenues from tax amnesties will provide an important contribution to the state treasury & 76,1 \\
\hline 7 & I think that tax amnesties will boom the economy & 75,8 \\
\hline 8 & I care more about the enactment of premium amnesties than the enactment of tax amnesties & 74,4 \\
\hline 9 & The fact that tax amnesties come into effect at regular intervals can affect my economic decisions positively & 73,9 \\
\hline 10 & I think that tax amnesties are important agreements to make peace with the state. & 72,2 \\
\hline 11 & Tax amnesty can strengthen the cooperation between the taxpayer and the tax administration & 72,2 \\
\hline 12 & The fact that tax amnesties could come into force at any time gives me confidence & 71,3 \\
\hline 13 & I believe that tax amnesties should come into effect at regular intervals & 70,8 \\
\hline 14 & I believe that the premium amnesty is more acceptable than tax amnesty & 70,2 \\
\hline 15 & The fact that tax amnesties come into effect at certain periods can affect my mood positively & 68,3 \\
\hline 16 & Tax amnesties can facilitate the transition of taxpayers from informal to formal economy & 66,6 \\
\hline 17 & I think that if taxpayers benefit from tax amnesty, that they should be audited more strictly & 64,3 \\
\hline 18 & I believe tax amnesty is a fair practice & 60,4 \\
\hline 19 & I believe that instead of tax amnesties, tax audits should be done more frequently & 58,1 \\
\hline 20 & $\begin{array}{l}\text { I believe that if the taxpayers benefit from the tax amnesty, they may pay the taxes more diligently in the } \\
\text { future }\end{array}$ & 56,7 \\
\hline 21 & I think that if taxpayers benefit from tax amnesty, they will be more conscious of tax responsibilities & 55,1 \\
\hline 22 & Tax amnesties implemented at certain times can lead to pay less tax & 41,0 \\
\hline 23 & I think that tax amnesties appear like rewards given to dishonest taxpayer & 35,4 \\
\hline 24 & I believe that tax amnesties will lead to an unfair competition in the economy & 34,3 \\
\hline 25 & Tax amnesties can encourage taxpayers to pay more taxes & 34,0 \\
\hline 26 & I believe that taxpayers should benefit from tax amnesties only once & 31,2 \\
\hline 27 & I think that tax amnesties weaken the authority of tax auditing & 28,4 \\
\hline 28 & I believe that tax penalties should be aggravated immediately after the tax amnesty has come into effect & 18,3 \\
\hline
\end{tabular}

\subsubsection{Comparison of the Views regarding Attitude Statements of the Tax Amnesty Beneficiaries and Tax Amnesty Non-Beneficiaries}

Table 5 compares result of frequency analysis regarding attitude statements of the participants who have not benefited and have benefited from the tax amnesty before. When Table 3 and Table 4 results are evaluated together, it is seen that both tax amnesty nonbeneficiaries and tax amnesty beneficiaries give similar responses regarding attitude statements towards tax amnesties. However, it is understood from tables that the tax amnesty non-beneficiaries support the first four attitude statements towards tax amnesty more than the tax amnesty beneficiaries. Similarly, it is seen from tables that the tax amnesty nonbeneficiaries advocate "I believe that the premium amnesty is more acceptable than tax amnesty" and "I care more about the enactment of premium amnesties than the enactment of tax amnesties" attitude statements more than the tax amnesty beneficiaries. On the other hand, results of two different tables show that the tax amnesty non-beneficiaries give support "I believe that taxpayers should benefit from tax amnesties only once", "I believe that tax amnesties will lead to an unfair competition in the economy", and "I believe that tax penalties should be aggravated immediately after the tax amnesty has come into effect" attitude statements less than the tax amnesty beneficiaries. Finally, conclusions of two different tables 


\section{$\int\left(\begin{array}{c}\text { Journal of Life } \\ \text { Economics }\end{array}\right.$}

indicate that the tax amnesty non-beneficiaries assess tax amnesties more fair in comparison to the tax amnesty beneficiaries. All these conclusions regarding the comparison of the attitude statements reveal that the tax amnesty non-beneficiaries support tax amnesties more than the tax amnesty beneficiaries.

\section{Table 5. Analysis of the Frequency Regarding Comparison of the Attitude Statements of the Tax Amnesty Beneficiaries and Tax Amnesty Non-Beneficiaries}

\begin{tabular}{|c|c|c|c|}
\hline No & ATTITUDE STATEMENTS & $\begin{array}{c}\text { Tax } \\
\text { Amnesty } \\
\text { Beneficiaries }\end{array}$ & $\begin{array}{c}\begin{array}{c}\text { Tax Amnesty } \\
\text { non- } \\
\text { Beneficiaries }\end{array} \\
\text { I AGREE }\end{array}$ \\
\hline 1 & When it comes to a serious economic downturn, I may support the tax amnesty & 79,4 & 84,3 \\
\hline 2 & $\begin{array}{l}\text { A tax amnesty that will come into effect for small businesses (micro business) in the } \\
\text { future will make me happy }\end{array}$ & 76,7 & 77,8 \\
\hline 3 & I care about reviving in the economy because of the tax amnesty & 75,5 & 77,8 \\
\hline 4 & I believe that the tax amnesties must come into force for sectors that are struggling & 75,5 & 82,9 \\
\hline 5 & $\begin{array}{l}\text { Tax amnesties can make the business life of taxpayers who get down due to not } \\
\text { fulfilling their tax obligations more efficient }\end{array}$ & 73,1 & 76,7 \\
\hline 6 & $\begin{array}{l}\text { The fact that tax amnesties come into effect at regular intervals can affect my } \\
\text { economic decisions positively }\end{array}$ & 72,7 & 73,9 \\
\hline 7 & $\begin{array}{l}\text { I think that the revenues from tax amnesties will provide an important contribution to } \\
\text { the state treasury }\end{array}$ & 72,3 & 76,1 \\
\hline 8 & I think that tax amnesties are important agreements to make peace with the state & 71,5 & 72,2 \\
\hline 9 & I think that tax amnesties will boom the economy & 71,5 & 75,8 \\
\hline 10 & I believe that the premium amnesty is more acceptable than tax amnesty & 70,0 & 70,2 \\
\hline 11 & $\begin{array}{l}\text { I care more about the enactment of premium amnesties than the enactment of tax } \\
\text { amnesties }\end{array}$ & 69,6 & 74,4 \\
\hline 12 & $\begin{array}{l}\text { Tax amnesties can facilitate the transition of taxpayers from informal to formal } \\
\text { economy }\end{array}$ & 68,4 & 66,6 \\
\hline 13 & $\begin{array}{l}\text { The fact that tax amnesties come into effect at certain periods can affect my mood } \\
\text { positively }\end{array}$ & 67,6 & 68,3 \\
\hline 14 & The fact that tax amnesties could come into force at any time gives me confidence & 66,4 & 71,3 \\
\hline 15 & I believe that tax amnesties should come into effect at regular intervals & 66,4 & 70,8 \\
\hline 16 & $\begin{array}{l}\text { I think that if taxpayers benefit from tax amnesty, that they should be audited more } \\
\text { strictly }\end{array}$ & 63,2 & 64,3 \\
\hline 17 & I believe that instead of tax amnesties, tax audits should be done more frequently & 59,7 & 58,1 \\
\hline 18 & $\begin{array}{l}\text { Tax amnesty can strengthen the cooperation between the taxpayer and the tax } \\
\text { administration }\end{array}$ & 59,7 & 72,2 \\
\hline 19 & I believe tax amnesty is a fair practice & 55,7 & 60,4 \\
\hline 20 & $\begin{array}{l}\text { I think that if taxpayers benefit from tax amnesty, they will be more conscious of tax } \\
\text { responsibilities }\end{array}$ & 55,3 & 55,1 \\
\hline 21 & $\begin{array}{l}\text { I believe that if the taxpayers benefit from the tax amnesty, they may pay the taxes } \\
\text { more diligently in the future }\end{array}$ & 54,9 & 56,7 \\
\hline 22 & Tax amnesties implemented at certain times can lead to pay less tax & 44,7 & 41,0 \\
\hline 23 & I think that tax amnesties appear like rewards given to dishonest taxpayer & 39,9 & 35,4 \\
\hline 24 & Tax amnesties can encourage taxpayers to pay more taxes & 39,5 & 34,0 \\
\hline 25 & I believe that tax amnesties will lead to an unfair competition in the economy & 38,7 & 34,3 \\
\hline 26 & I think that tax amnesties weaken the authority of tax auditing & 34,0 & 28,4 \\
\hline 27 & I believe that taxpayers should benefit from tax amnesties only once & 32,8 & 31,2 \\
\hline 28 & $\begin{array}{l}\text { I believe that tax penalties should be aggravated immediately after the tax amnesty } \\
\text { has come into effect }\end{array}$ & 24,1 & 18,3 \\
\hline
\end{tabular}

\subsection{Evaluation of the Results of Factor Analysis related to this Research}

Under this heading, first of all, the concept of factor analysis is briefly mentioned. Then, the Kaiser-Meyer-Olkin (KMO) test, which is included in the scope of factor analysis, is explained and the results related to relevant test with the scope of this study are discussed. 
After that, concept of "Total Variance Explained" regarding factor analysis is explained and a table related to this within the context of this research is interpreted. Thereafter, the concepts of factor analysis such as factor loadings, rotation of factor data and pattern matrix are expressed and the results which reveal in this research relation to this are presented.

\subsubsection{Concept of Factor Analysis}

Factor analysis is used to reduce data in statistics literature. Through this analysis it is possible to decrease data complexity (Nargundkar, 2007: 312). In other words, factor analysis helps to explain a wider range of variables with fewer variables (Diamantopoulos and Schlegelmilch, 2000: 216). Factor analysis assumes that there is a relationship between variables and builds that assumption on this basis. This analysis is conceptually divided into two. One is exploratory factor analysis and the other is confirmatory factor analysis (İslamoğlu and Alnıaçık, 2014: 396). Exploratory factor analysis helps summarize the data. These data consist of interrelated variables. At the same time, these data have an appropriate appearance to be grouped together. Confirmatory factor analysis is based on the constructs of variables. With this analysis, hypotheses about the structure of variables are tested (Munro, 2005: 324). In this study, explanatory factor analysis is used.

\subsubsection{Concept of Kaiser-Meyer-Olkin (KMO) and Interpretation of Relevant Concept in This Research Framework}

Kaiser-Meyer-Olkin (KMO) shows the dimension of the correlation between the variables (Hinton et al., 2004: 349). It analyses whether factor analysis can be performed on existing data (Verma, 2016: 341). In order to interpret the Kaiser-Meyer-Olkin (KMO) value, KMO measure of sampling adequacy value should not be below 0.50. It is desirable that this value is greater than 0.70 (Leech et al., 2005: 94). If this value is above 0.90, it is marvelous (CGAP, 2003: 139). KMO measure of sampling adequacy value for this research is 0.95 . According to statistics literature, the founded value towards this fieldwork is magnificent (Table 6). The "Bartlett's Test of Sphericity" provides information on the adequacy of the correlation matrix. In other words The "Bartlett's Test of Sphericity" analyzes whether the correlation between variables is sufficient (Ho, 2006: 218). If the significance value for the "Bartlett's Test of Sphericity" is less than 0.05, this result indicates that the study data are suitable for factor analysis (George and Mallery, 2016: 264). The significance value for "Bartlett's Test of Sphericity" towards this research is 0,000 . Therefore, the study data for this fieldwork is proper in order to factor analysis (Table 6).

Table 6. KMO and Bartlett's Test

\begin{tabular}{|c|c|c|}
\hline \multicolumn{2}{|c|}{ Kaiser-Meyer-Olkin Measure of Sampling Adequacy. } & 9950 \\
\hline \multirow[t]{3}{*}{ Bartlett's Test of Sphericity } & Approx. Chi-Square & 8098,409 \\
\hline & Df & 378 \\
\hline & Sig. &, 000 \\
\hline
\end{tabular}

\subsubsection{Explanation of the Concept of "Total Variance Explained" and Interpretation of This Concept within the scope of The Research}

In order to express "Total Variance Explained", eigenvalue has a decisive feature (Foster, 2001: 234). In the description of "Total Variance Explained", eigenvalues greater than 1 should be considered. There is a factor number up to eigenvalue which is greater than 


\section{$\int$ Journal of Life \\ Economics}

1 (Acton et al., 2009: 248). Factor concept is also expressed as a component at the same time in statistics literature (Brace, 2016: 338). The "total variance explained" table also shows the total variance value for each component (factor). The factor or components whose eigenvalue is greater than 1 meet a certain percentage of the total variation (Kaur, 2015: 69). In the light of this data, "Total Variance Explained" within the scope of the factor analysis regarding this study reveals five different components or factors more than one eigenvalue value (Table 7). On the other hand, it is suggested that the cumulative value of "total variance Explained" should be between 50\% and 90\% (Dawson, 2017: 43). The cumulative value of "total variance explained" for this study was determined as 58, 266\%. Therefore, this figure is compatible with the literature.

Table 7. Total Variance Explained within the scope of Factor Analysis

\begin{tabular}{|c|c|c|c|c|c|c|c|}
\hline \multirow{2}{*}{ Component } & \multicolumn{3}{|c|}{ Initial Eigenvalues } & \multicolumn{3}{|c|}{ Extraction Sums of Squared Loadings } & \multirow{2}{*}{$\begin{array}{c}\begin{array}{c}\text { Rotation Sums of } \\
\text { Squared Loadings }\end{array} \\
\text { Total } \\
\end{array}$} \\
\hline & Total & $\%$ of Variance & Cumulative \% & Total & $\%$ of Variance & Cumulative \% & \\
\hline 1 & 10,462 & 37,366 & 37,366 & 10,462 & 37,366 & 37,366 & 9,704 \\
\hline 2 & 2,524 & 9,014 & 46,380 & 2,524 & 9,014 & 46,380 & 5,541 \\
\hline 3 & 1,205 & 4,303 & 50,683 & 1,205 & 4,303 & 50,683 & 2,242 \\
\hline 4 & 1,097 & 3,918 & 54,601 & 1,097 & 3,918 & 54,601 & 3,293 \\
\hline 5 & 1,026 & 3,664 & 58,266 & 1,026 & 3,664 & 58,266 & 1,810 \\
\hline 6 & ,971 & 3,467 & 61,733 & & & & \\
\hline 7 & ,813 & 2,904 & 64,637 & & & & \\
\hline 8 & ,782 & 2,791 & 67,428 & & & & \\
\hline 9 & ,735 & 2,624 & 70,051 & & & & \\
\hline 10 & ,711 & 2,540 & 72,592 & & & & \\
\hline 11 & ,642 & 2,291 & 74,883 & & & & \\
\hline 12 & 605 & 2,161 & 77,044 & & & & \\
\hline 13 & ,555 & 1,982 & 79,025 & & & & \\
\hline 14 &, 552 & 1,970 & 80,995 & & & & \\
\hline 15 & ,513 & 1,833 & 82,828 & & & & \\
\hline 16 & ,466 & 1,665 & 84,493 & & & & \\
\hline 17 & ,463 & 1,652 & 86,145 & & & & \\
\hline 18 & ,442 & 1,577 & 87,723 & & & & \\
\hline 19 & ,412 & 1,473 & 89,195 & & & & \\
\hline 20 & ,404 & 1,443 & 90,639 & & & & \\
\hline 21 & ,388 & 1,386 & 92,024 & & & & \\
\hline 22 & ,376 & 1,344 & 93,369 & & & & \\
\hline 23 & ,361 & 1,291 & 94,660 & & & & \\
\hline 24 & ,353 & 1,260 & 95,920 & & & & \\
\hline 25 & ,337 & 1,204 & 97,124 & & & & \\
\hline 26 & ,312 & 1,114 & 98,238 & & & & \\
\hline 27 & ,279 & ,996 & 99,234 & & & & \\
\hline 28 & ,214 & ,766 & 100,000 & & & & \\
\hline
\end{tabular}

\subsubsection{Explanation of Other Basic Concepts related to Factor Analysis}

Under this heading two main concepts of factor analysis are mentioned. One of these concepts is factor loadings and the other is factor rotation. In this context, firstly the concept of factor loadings related to factor analysis is explained. Then, factor rotation is mentioned.

\subsubsection{Explanation of Factor Load Concept within the Scope of Factor Analysis}

Factor loadings of variables have a decisive feature in factor analysis. It is not possible to comment on the correlation between the variables and the factors or components without 


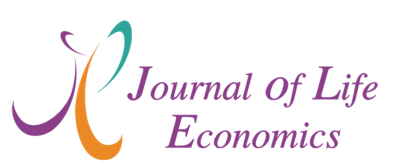

factor loads (Burns and Burns, 2008: 446). In principle, factor loads are expected to be not lower than 0.30. On the other hand, if the factor load is greater than 0.40 and 0.40 , this level is considered as high (Leech et al., 2005: 95). In the factor analysis conducted for this study, the factor loadings were determined to be greater than 0.40. Therefore, the factor loads put forward in this study seem to be suitable for statistical interpretation (Table 8). At this point, to talk about the concept of rotation for factor analysis will be complementary.

\subsubsection{Explanation of Factor Rotation Concept Regarding Factor Analysis}

Theoretically, the concept of factor rotation is a concept that helps to produce the results more interpretable in terms of statistical. Factor rotation helps to change factor loads that establish a mutual relation between variables and components (Swanson and Holton, 2005: 192). Factor rotation has two basic forms. One of them is oblique rotation and the other is orthogonal rotation (Brown, 2015: 27). Orthogonal rotation is a type of rotation that neglects the relationship of two or more factors to each other. There are three different orthogonal rotation types in theory. The first one is varimax rotation, the second is quartimax rotation, and the third is equimax rotation (Meyers vd., 2006: 499-500).

If factors are rotated by means of factor analysis and relevant factors between these factors are taken into account, in this case, it is possible to mention from oblique rotation (Asthana and Bhushan, 2016: 206). At the same time, oblique rotation is a type of rotation that reveals the relationship between variables and factors (Lee and Ashton, 2007: 434). The factor matrix is divided into two by the oblique rotation. One of the matrixes resulting from the division of this factor matrix is the pattern matrix. This matrix is a simple-looking matrix type used by most researchers (Field, 2000: 465). The pattern matrix takes into account the correlational relationship between variables and components (Bryman and Cramer, 2001: 270). In the light of this information, in this research, oblique method is adopted and pattern matrix results are taken into consideration. 


\section{(Journal of Life \\ Economics}

Table 8. The Scoring of Factor Loads about Attitude Statements Regarding Tax Amnesty (Table regarding Replacement of Factor Loads by Pattern Matrix)

\begin{tabular}{|c|c|c|c|c|c|c|}
\hline No & Attitude Statements & $\begin{array}{c}\text { Attitudes } \\
\text { towards } \\
\text { Tax } \\
\text { Amnesty } \\
\text { Expectation }\end{array}$ & $\begin{array}{l}\text { Negative } \\
\text { or } \\
\text { Cautious } \\
\text { Attitudes } \\
\text { Towards } \\
\text { Tax } \\
\text { Amnesty }\end{array}$ & $\begin{array}{c}\text { More } \\
\text { Supportive } \\
\text { Attitudes in } \\
\text { relation to } \\
\text { Premium } \\
\text { Amnesty } \\
\text { compared } \\
\text { to Tax } \\
\text { Amnesty }\end{array}$ & $\begin{array}{c}\text { Optimistic } \\
\text { Attitudes } \\
\text { Towards } \\
\text { Tax } \\
\text { Amnesty }\end{array}$ & $\begin{array}{c}\text { Attitudes } \\
\text { which } \\
\text { Support } \\
\text { Tax } \\
\text { Auditing } \\
\text { compared } \\
\text { to Tax } \\
\text { Amnesty }\end{array}$ \\
\hline 1 & $\begin{array}{l}\text { I think that tax amnesties are important agreements to make peace } \\
\text { with the state }\end{array}$ & 880 & & & & \\
\hline 2 & $\begin{array}{l}\text { I care about reviving in the economy because of the tax } \\
\text { amnesty }\end{array}$ &, 854 & & & & \\
\hline 3 & $\begin{array}{l}\text { Tax amnesty can strengthen the cooperation between the } \\
\text { taxpayer and the tax administration }\end{array}$ &, 821 & & & & \\
\hline 4 & $\begin{array}{l}\text { Tax amnesties can make the business life of taxpayers who } \\
\text { get down due to not fulfilling their tax obligations more } \\
\text { efficient }\end{array}$ & ,798 & & & & \\
\hline 5 & $\begin{array}{l}\text { The fact that tax amnesties could come into force at any time gives } \\
\text { me confidence }\end{array}$ &, 778 & & & & \\
\hline 6 & $\begin{array}{l}\text { When it comes to a serious economic downturn, I may support the } \\
\text { tax amnesty }\end{array}$ & ,730 & & & & \\
\hline 7 & $\begin{array}{l}\text { I believe that the tax amnesties must come into force for sectors } \\
\text { that are struggling }\end{array}$ & ,715 & & & & \\
\hline 8 & $\begin{array}{l}\text { I think that the revenues from tax amnesties will provide an } \\
\text { important contribution to the state treasury }\end{array}$ & ,603 & & & & \\
\hline 9 & $\begin{array}{l}\text { I believe that tax amnesties should come into effect at } \\
\text { regular intervals }\end{array}$ & 600 & & & & \\
\hline 10 & I think that tax amnesties will boom the economy & ,595 & & & & \\
\hline 11 & $\begin{array}{l}\text { A tax amnesty that will come into effect for small } \\
\text { businesses (micro business) in the future will make me } \\
\text { happy }\end{array}$ &, 551 & & & & \\
\hline 12 & $\begin{array}{l}\text { The fact that tax amnesties come into effect at certain } \\
\text { periods can affect my mood positively }\end{array}$ &, 548 & & & & \\
\hline 13 & I believe tax amnesty is a fair practice & ,511 & & & & \\
\hline 14 & $\begin{array}{l}\text { The fact that tax amnesties come into effect at regular } \\
\text { intervals can affect my economic decisions positively }\end{array}$ &, 505 & & & & \\
\hline 15 & $\begin{array}{l}\text { Tax amnesties can facilitate the transition of taxpayers from } \\
\text { informal to formal economy }\end{array}$ & ,496 & & & & \\
\hline 16 & $\begin{array}{l}\text { Tax amnesties implemented at certain times can lead to pay } \\
\text { less tax }\end{array}$ & & ,735 & & & \\
\hline 17 & $\begin{array}{l}\text { I think that tax amnesties appear like rewards given to } \\
\text { dishonest taxpayer }\end{array}$ & & 688, & & & \\
\hline 18 & $\begin{array}{l}\text { I believe that taxpayers should benefit from tax amnesties } \\
\text { only once }\end{array}$ & & 664, & & & \\
\hline 19 & $\begin{array}{l}\text { I believe that tax amnesties will lead to an unfair competition in the } \\
\text { economy }\end{array}$ & & 610 & & & \\
\hline 20 & $\begin{array}{l}\text { I think that tax amnesties weaken the authority of tax } \\
\text { auditing }\end{array}$ & & ,584 & & & \\
\hline 21 & $\begin{array}{l}\text { I believe that tax penalties should be aggravated immediately after } \\
\text { the tax amnesty has come into effect }\end{array}$ & & ,473 & & & \\
\hline 22 & $\begin{array}{l}\text { I believe that the premium amnesty is more acceptable than } \\
\text { tax amnesty }\end{array}$ & & &,- 788 & & \\
\hline 23 & $\begin{array}{l}\text { I care more about the enactment of premium amnesties than } \\
\text { the enactment of tax amnesties }\end{array}$ & & & -687 & & \\
\hline 24 & Tax amnesties can encourage taxpayers to pay more taxes & & & &,- 760 & \\
\hline 25 & $\begin{array}{l}\text { I think that if taxpayers benefit from tax amnesty, they will be } \\
\text { more conscious of tax responsibilities }\end{array}$ & & & &,- 482 & \\
\hline 26 & $\begin{array}{l}\text { I believe that if the taxpayers benefit from the tax amnesty, they } \\
\text { may pay the taxes more diligently in the future }\end{array}$ & & & &,- 404 & \\
\hline 27 & $\begin{array}{l}\text { I believe that instead of tax amnesties, tax audits should be done } \\
\text { more frequently }\end{array}$ & & & & & ,783 \\
\hline 28 & $\begin{array}{l}\text { I think that if taxpayers benefit from tax amnesty, that they should } \\
\text { be audited more strictly }\end{array}$ & & & & & ,748 \\
\hline
\end{tabular}




\subsubsection{Assessing of Table regarding Replacement of Factor Loads by Pattern} Matrix

Table 8 shows that all attitude statements are divided into 5 different groups. This grouping is determined according to the results of factor analysis. According to Table 8, factor scores for attitude statements show significant results in terms of statistical. This table shows that the attitude statements between 1 and 15 are collected in heading "Attitudes towards Tax Amnesty Expectation", the attitude statements between 16 and 21 are collected in heading "Negative or Cautious Attitudes towards Tax Amnesty", the attitude statements between 22 and 23 are collected in heading "More Supportive Attitudes in relation to Premium Amnesty compared to Tax Amnesty", the attitude statements between 24 and 26 are collected in heading "Optimistic Attitudes towards Tax Amnesty", the attitude statements between 27 and 28 are collected in heading "Attitudes which Support Tax Auditing compared to Tax Amnesty". When attitude statements grouped by factor analysis are handled one by one, the following can be said;

-All of attitude statements are collected in heading "Attitudes towards Tax Amnesty Expectation" express that the respondents who support these attitude statements may enter into the expectation of tax amnesty.

-All of attitude statements are collected in heading "Negative or Cautious Attitudes towards Tax Amnesty" point out that the respondents who advocate these attitude statements may not want to be applied to tax amnesties.

-All of attitude statements are collected in heading "More Supportive Attitudes in relation to Premium Amnesty compared to Tax Amnesty" state that the respondents who encourage these attitude statements may prefer to pay their premium amnesties instead of tax amnesties.

-All of attitude statements are collected in heading "Optimistic Attitudes towards Tax Amnesty" reveal that the respondents who promote these attitude statements may resort to tax amnesties.

-All of attitude statements are collected in heading "Attitudes which Support Tax Auditing compared to Tax Amnesty" indicate that the respondents who corroborate these attitude statements may prefer to implement tax auditing instead of applying tax amnesty.

\section{CONCLUSION}

According to the results of this research, most of tax amnesty beneficiaries and nonbeneficiaries grant "I think that the revenues from tax amnesties will provide an important contribution to the state treasury" attitude statement at almost $70 \%$ level on average. This result is not supported with the literature study made by Uchitelle (1989) and the result of research conducted by Laborda and Rodrigo (2003). Furthermore, while this result supports the literature view Alm (1998) that tax amnesty can contribute to the treasury in the short term, it doesn't support the results of belonging to the research Alm and Beck (1993) and Christian et al. (2002) that tax amnesty can contribute to the treasury in the long term.

These results show that most of the tax amnesty beneficiaries $(68.4 \%)$ and the nonbeneficiaries $(66.6 \%)$ grant "tax amnesties can facilitate the transition of taxpayers from informal to formal economy" attitude statement. Additionally, these results indicate that most of tax amnesty beneficiaries (71.5\%) and non-beneficiaries $(72.2 \%)$ grant "I think that tax amnesties are important agreements to make peace with the state" attitude statement. These 


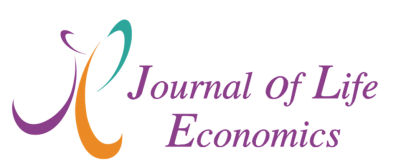

results are advocated by the literature study made by Andreoni, (1991) and Karg1 (2011). In addition, this study points out that less than $50 \%$ of tax amnesty beneficiaries $(39.9 \%)$ and non-beneficiaries (35.4\%) advocate "I think that tax amnesties appear like rewards given to dishonest taxpayer" attitude statement. This conclusion does not show compatibility with result of the research by conducted Tuay and Güvenç (2007). Moreover, result of this study demonstrates that most of tax amnesty beneficiaries (72.7\%) and non-beneficiaries $(73.9 \%)$ support "The fact that tax amnesties come into effect at regular intervals can affect my economic decisions positively" attitude statement. The result of research conducted by Çelikkaya and Gürbüz (2008) is incompatible with this conclusion. It is possible to make a few suggestions within the scope of these results. The short and long term contribution of tax amnesties to state treasury can be improved by considering the supportive attitudes regarding this research. In the context of these research results, the relationship between tax compliance and tax amnesty can be strengthened by taking into consideration the supportive attitudes towards this study. 


\section{$\int\left(\begin{array}{c}\text { Journal of Life } \\ \text { Economics }\end{array}\right.$}

\section{REFERENCES}

ACTON, C., Miller, R., FUllertON, D., MALTBY, J., (2009). SPSS Statistics for Social Scientists, Second Edition, Palgrave Macmillan.

ANDREONI, J., (1991). The Desirability of a Permanent Tax Amnesty, Journal of Public Economics, 45, 143-159.

ALM, J., BECK, W., (1993). Tax Amnesties and Compliance in the Long Run: A Time Series Analysis, National Tax Journal, Vol. 46, No.1, 53-60.

ALM, J., (1998). Tax Policy Analysis: The Introduction of a Russian Tax Amnesty, International Studies Program, Georgia State University, Working Paper 98-6, file://C:/Users/asus/Downloads/SSRN-id471321.pdf, Date Accessed: 08.08.2017.

ASTHANA, H. S., BHUSHAN, B., (2016). Statistics for Social Science, 2. Edition, PHI, Delhi.

BAER, K., BORGNE, E. L., (2008). Tax Amnesties: Theory, Trends, and Some Alternatives, IMF, USA.

BENK, S., BUDAK, T., ÇAKMAK, A. F., (2012). Tax Professionals' Perceptions of Tax Fairness: Survey Evidence in Turkey, International Journal of Business and Social Science, Vol. 3, No.2, 112-117.

BLACK, K., (2010). Business Statistics, 6.Edition, John Wiley \& Sons, Inc., USA.

BRACE, N., KEMP, R., SNELGAR, R., (2016). SPSS for Psychologists, 6. Edition, Palgrave.

BROWN, Timothy (2015), Confirmatory Factor Analysis for Applied Research, Guilford Press, USA.

BRYMAN, A., CRAMER, D., (2001). Quantitative Data Analysis with SPSS Release 10 for Window, Routledge, USA and Canada.

BURNS, R. B., BURNS, R. A., (2008). Business Research Methods and Statistics Using SPSS, SAGE Publication Ltd.,

CGAP (2003). Microfinance Poverty Assessment Tool, The World Bank, USA.

CHRISTIAN, C. W., GUPTA, S., YOUNG, J. J., (2002). Evidence on Subsequent Filing from the State of Michigan's Income Tax Amnesty, National Tax Journal, Vol. 55, No.4, 703-721.

ÇELIKKAYA, A., GÜRBÜZ, H., (2008). Mükelleflerin Vergiye Karşı Tutum ve Davranışlarını Etkileyen Çeşitli Değişkenler Arasındaki İlişkinin Analizi [Analyzing the Relationship among Variables That Affect the Behavior of Taxpayer against Tax, SosyoEkonomi, 23-54.

DAWSON, J., (2017). Analysing Quantitative Survey Data, Sage.

DIAMANTOPOUlOS, A., SCHLEGELMILCH, B. B., (2000). Taking the Fear Out of Data Analysis, Thomson, London.

DEMIR, M., DEMIRGIL, B., İTIK, Ü. M., DENIZ, Y., (2016). Vergi Dairesi Personeli Açısından Vergi Aflarının Etkinliği: Sivas İlinde Bir Araştırma, C.Ü. İktisadi ve İdari Bilimler Dergisi, Volume 17, Number 2, 275-302. 


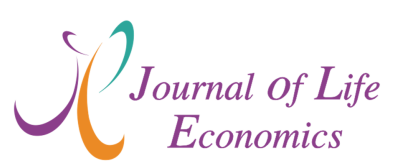

EDİZDOĞAN, N., GÜMÜŞ, E., (2013). Vergi Afları ve Türkiye'deki Vergi Aflarının Değerlendirilmesi [Tax Amnesties and Evaluation of the Tax Amnesties in Turkey], Maliye Dergisi, Number 164, 99-119.

FIELD, A., (2000). Discovering Statistics Using SPSS for Windows, Sage Publications, Great Britain.

FOSTER, J. J., (2001). Data Analysis, Using SPSS for Window, Sage Publication.

GEORGE, D., MALLERY, P., (2016). IBM SPSS Statistics 23 Step by Step, Routledge, 14. Edition, USA.

HINTON, P. R., BROWNLOW, C., MCMURRAY, I., COZENS, B., (2004). SPSS Explained, Routledge, USA.

İSLAMOĞLU, H., ALNIAÇIK Ü., (2014). Sosyal Bilimlerde Araştırma Yöntemleri, Beta, 4. Edition, Istanbul.

İPEK, S., KAYNAR, İ., (2012). Vergi Aflarının Yükümlü Psikolojisi Açısından Değerlendirilmesi [The Evaluation of Tax Amnesty from Tax-Payer's Perspective: The Example of Thrace Region], Hukuk ve İktisat Araştırmaları Dergisi, Volume: 4, Number: 1, 245-253.

KARGI, V., (2011). Türkiye'de Vergi Aflarının Vergi Gelirine Etkisi [Effects of The Tax Amnesties on Tax Revenues In Turkey], ZKÜ Journal of Social Science, Volume 7, Number 13, 101-115.

KAUR, P., (2015). An Empirical Study on Factors Affecting Faculty Retention in India Business Schools, Maneging in Recovering Markets, Editors: S. Chatterjee, N.P. Singh, D.P.Goyal, Narain Gupta, Springer, India.

LABORDA, J. L., RODRIGO F., (2003). Tax Amnesties and Income Tax Compliance: The Case of Spain, Fiscal Studies, Volume 24, Issue 1, 73-96.

LEE, K., ASHTON, M. C., (2007). Factor Analysis in Personality Research, 424-443, Handbook of Research Methods in Personality Psychology, Editors: Richard W. Robins, R. Chris Fraley, Robert F. Krueger, The Guilford Press, USA.

LEECH, N. L., BARRETT, K. C., MORGAN, G. A., (2005). SPSS for Intermediate Statistics: Use and Interpretation, Second Edition, New Jersey, USA.

MEYERS, L. S., GAMST, G., GUARINO, A. J., (2006). Applied Multivariate Research, Sage Publications, USA.

MCGEE, R. W., DEVOS, K., BENK, S., (2016). Attitudes towards Tax Evasion in Turkey and Australia: A Comparative Study, MDPI, Social Science, 1-13.

MUNRO, B. H., (2005). Statistical Methods for Health Care Research, 5. Edition, Lippincott Williams \&Wilkins, USA.

NARGUNDKAR, R., (2007). Marketing Research, 2. Edition, Tata McGraw-Hill Publishing, New Delhi.

POLIT, D. F., BECK, C. T., (2004). Nursing Research: Principles and Methods, Lippincott Williams \& Wilkins, 7. Edition, USA.

ROBERT H., (2006), Handbook of Univariate and Multivariate Data Analysis and İnterpretation with SPSS, Chapman \& Hall / CRC, USA, 2006. 


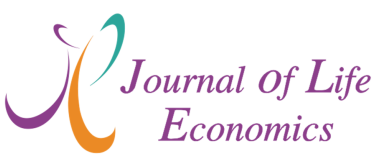

SARAÇOĞLU, O. F., ÇAŞKURLU, E., (2011). Tax Amnesty with Effects and Effecting: Tax Compliance, Tax Audits and Enforcement Around; The Turkish Case, International Journal of Business and Social Science, Vol: 2, No: 7, 95-103.

SAVAŞAN, F., (2006). Vergi Aflanı: Teori ve Türkiye Uygulamaları ("Vergi Barışı" Uygulama Sonuçları), Afyon Kocatepe Üniversitesi, İ̈BF Dergisi, Valume 8, Number $1,41-65$.

SWANSON, R. A., HOLTON, E. F., (2005). Reseach in Organizations: Foundation and Methods in Inquiry, Berret-Koehler Publishers, USA.

TEKIN, A., TUNCER, G., SAĞDIÇ, E. N. (2013). Vergi Afları Sonrasında Vergi Uyumu Süreci[Tax Compliance Process After Tax Amnesties], The Sakarya Journal of Economics, 1-26.

TORGLER, B., (2007). Tax Compliance and Tax Morale, Edward Elgar, UK.

TUAY, E., GÜVENÇ, İ., (2007). Türkiye'de Mükelleflerin Vergiye Bakışı [Taxpayer's View of Taxation in Turkey], Gelir İdaresi Başkanlığı, Edition Number: 51.

UCHITELLE, E., (1989). The Effectiveness of Tax Amnesty Programs in Selected Countries, Econpapers, 48-53.

VERMA, J. P., (2016). Sports Research with Analytical Solution Using SPSS, WILEY, USA and Canada.

WESTLAND, C. J., (2015). Structural Equation Models: From Paths to Networks, Springer, Switzerland. 